\title{
A manutenção das oligarquias no poder: as transformações econômico-políticas e a permanência dos privilégios sociais
}

\author{
Claudia Wasserman*
}

Resumo - Esse trabalho discute o tema da crise das oligarquias na América Latina, ressaltando nāo os aspectos do desenvolvimento capitalista ensejado por esses grupos, mas a persistência de certas características desses setores das classes dominantes no subcontinente.

Abstract - This paper discusses the oligarchy crisis on Latin-America, emphasizing not a view of capitalism growth leaded by oligarchy, but preservation attribute of those dominant groups in Latin-America.

Palavras-chave - História da América Latina - Estado Oligárquico - Força da tradição.

Key words - Latin-american history - Oligarchical State - Power of tradition.

A historiografia contemporânea latino-americana indica o ano de 1910 como aquele no qual ocorreu a ruptura da sociedade oligárquica, como conseqüência da Revolução Mexicana. Apontam este momento como decisivo para o esgotamento do sistema de articulação social e política até então vigentes. À Revolução Mexicana seguiram-se outros

* Professora assistente do Departamento de História da Ufros, setor de História da América. E-mail: cwasscrman( $\alpha$ pro.via-rs.com.br

Estudos Ibero-Americanos. PUCRS, v. XXIV, n. 2, p. 51-70, dezembro 1998 
episódios que auxiliam na comprovação dessa tese, como a Reforma Universitária de Córdoba, na Argentina, em 1918, cujo lema principal era "ha llegado la hora americana", em referência à contrariedade ao imperialismo e às oligarquias no poder; o Movimento Tenentista, no Brasil, desde 1922, que em armas questionava a ordem oligárquica reivindicando reformas político-eleitorais; os protestos de inquilinos, no Panamá, em 1925, que embora tenha começado como uma revolta em relação ao aumento dos aluguéis, transformara-se em uma espetacular rebelião anti-oligárquica que provocou uma sangrenta repressão norte-americana.

Estes e tantos outros episódios, não necessariamente simultâneos, foram considerados como o processo de derrocada das oligarquias e também do predomínio quase absoluto do setor primário-exportador em aliança com o capital monopólico.

No entanto, a simples observação empírica das realidades nacionais latino-americanas indica que as oligarquias ainda sobrevivem nas heranças que legaram ao sistema econômico, político, social e ideológico desses países, exemplificadas na força do latifúndio, na violência das relaçốes sociais no campo, no tipo de sistema produtivo extensivo de alguns rincões e na imensa concentração de renda, poder e terras na maior parte da América Latina.

Quem pode afirmar com absoluta certeza que, diante da existência de "currais eleitorais", violência eleitoral traduzida no assassinato de candidatos, manutenção de relações quase servis em algumas propriedades rurais, privilégio fiscal quase ilimitado aos grandes proprietários e a enorme influência das organizações ruralistas nos atuais governos "democráticos", as oligarquias latino-americanas foram derrotadas pelas "burguesias nacionais" em 1929, por conta da crise da Bolsa de Valores de Nova Iorque, ou em 1945, ao final da II Guerra Mundial, e, até mesmo, depois da Revoluçāo Nicaragüense de 1979?

Este ensaio é inspirado na tese de Arno J. Meyer, em A força da tradiçāo: a persistência do Antigo Regime (1848-1914), cujo título traduz de certa forma a idéia central do trabalho que, centrado na realidade européia na virada do século XIX para o século XX, coloca ênfase nas chamadas "forças da permanência", ao invés de investigar as causas da modernização e do progresso, aspectos muito mais evidentes no período de Revoluções burguesas. ${ }^{1}$

1 MEXER, Arno J. A força da tradição: a persistência do Antigo Regime (18481914). São Paulo: Cia das Letras, 1990. 
Na América Latina, o período de hegemonia das oligarquias coincide com o processo de implantaçăo do capitalismo nos países do subcontinente, por isso, economistas, historiadores e sociólogos costumam exagerar nos efeitos da importação de tecnologia inglesa, como ferrovias e portos, e nas conseqüências do sucesso da exportação de produtos primários. Tudo é tido como modernização e progresso, e, embora reconheçam o "espírito retrógrado" das oligarquias, acreditam que a extensão e consolidação do modo de produção capitalista na América Latina provocou a paulatina depressão da sociedade tradicional.

Arno Meyer observa que, para a história européia,

"houve assim uma tendência marcante a negligenciar, subestimar e desvalorizar a resistência de velhas forças e idéias e o seu astucioso talento para assimilar, retardar, neutralizar e subjugar a modernização capitalista, incluindo até mesmo a industrialização."2

Pode-se observar essa mesma propensão para o estudo do período oligárquico na América Latina, onde o desenvolvimento urbanoindustrial, o aparecimento de classes médias urbanas, do proletariado e de uma incipiente burguesia pareciam determinar o fim definitivo das classes tradicionais.

No entanto, o capitalismo não se implanta na América Latina mediante uma revolução democrático-burguesa e, longe de abolir o latifúndio tradicional, o conserva como chave de toda a evolução.

Com isso, não se quer dizer que os grupos oligárquicos tenham mantido uma hegemonia duradoura, ou que o modo de produção capitalista não tenha há muito se consolidado nos países latinoamericanos, mas que apesar dessa extensão e consolidação do capitalismo, as oligarquias conseguiram, na maior parte dos casos, ultrapassar a decadência do período de transição mantendo-se próximas ao poder, não mais como grupo dominante e coeso, porém influente.

As explicaçốes dessa persistência encontram-se justamente no modo como se implantou o capitalismo na América Latina, na formação das classes dominantes e na particular estrutura de classes conseqüente destas transformaçôes capitalistas.

Os grupos dominantes nos países latino-americanos constituíramse como tais ao longo dos processos de independência e de formação

2 Meyer, ibidem, p. 14. 
dos Estados nacionais. As independências surgiram como resultado da maturidade da crise de estrutura do sistema colonial, conjugada com o fato de existirem grupos sociais que controlavam os aparatos produtivos coloniais e entraram em contradição com as metrópoles. Às independências seguiram-se lutas intestinas determinadas pela imensa autonomia dos segmentos econômicos; forças centrífugas, caracterizadas pela dispersão das zonas produtivas e ausência de circulaçáo interna.

Segundo Agustín Cueva este período é

"la fase denominada de 'anarquia', que nos es otra cosa que el tormentoso camino que nuestras formaciones sociales tienen que recorrer hasta constituir sus estados nacionales, corresponde en términos generales al desarrollo de una estructura que partindo de una situación de equilibrio inestable de diversas formas productivas llega a una situación de predominio relativamente consolidado del modo de producción capitalista." ${ }^{\prime 3}$

Em outras palavras, as disputas que se expressavam como regionais, tal como na Argentina, a Iuta entre "litoral" e "interior", eram molduras espaciais onde iam se configurando diferentes relações de produção, e remetiam à tentativa de imposição de um grupo mais vigoroso sobre os demais, ou a um equilíbrio entre diversos grupos, naquelas regiões onde nenhum conseguia destaque.

Caracterizado pela forte estagnação econômica, desarticulação dos centros produtivos e fuga de metal precioso circulante, o período de anarquia só fez aumentar o poder das oligarquias regionais que controlavam desde o período colonial os centros produtivos regionais. Estas oligarquias foram as únicas em condições de disputar o poder dos novos Estados, pois como salienta T. Halperin Dongui, para o período de destruição posterior as guerras de independência,

"todavia, conserva-se intacta a fonte de uma riqueza que poderá ser reconstituída: a terra, com a qual os proprietários conseguirão refazer um patrimônio, tanto mais facilmente quanto mais cresceu o seu poder político."

3 CUEVA, Agustín. El desarrollo del capitalismo en América Latina. México: Siglo XXI, 1977, p. 41.

4 Halperin dongui, Tulio. História da América Latina. Rio de Janeiro: Paz e Terra, 1975, p. 86. 
A possibilidade de rearticular a produção primária aliada às aspirações inglesas de ter hegemonia no comércio com os novos países foram fundamentais para a saída da crise e também para consolidação de grupos oligárquicos dominantes, ou seja, aqueles cujos produtos tradicionais tivessem um mercado garantido nos centros mundiais do capitalismo. Em estudo precedente, esta situação foi explicada assim,

"[...] o Estado nacional na América Latina constituiu-se quando um setor da oligarquia ou um grupo importante de proprietários rurais, em regiôes bem cotadas e com produção importante para exportação, conseguiu consolidar-se como classe economicamente dominante e politicamente hegemônica. Este setor elimina o jacobinismo advindo da participação de mais classes sociais nos processos de independência, e a oligarquia central assume compromissos com os grupos periféricos, cujos produtos eram preteridos no mercado mundial. $" 5$

Praticamente todos os países da América Latina atingiram este equilíbrio por volta de 1880 , em estreita relação com o aumento da demanda internacional de produtos primários e o início da fase imperialista do capitalismo central. Na Argentina, por exemplo, o regime político das oligarquias vai atingindo maturidade no momento da união de interesses entre os grandes proprietários do litoral, comerciantes estrangeiros e investidores do setor de transportes no governo do general Roca em 1880; no México, o governo de Porfirio Díaz passou, desde 1876 até a Revolução de 1910, a representar os interesses do grande latifúndio de cana-de-açúcar, dos proprietários mineiros do norte e do capital monopolista em aliança com os primeiros; no Peru, a ditadura de Augusto Leguia (1919-1930) representava os interesses da economia mineradora que experimentou um grande crescimento neste período; no Brasil, o governo Campos Sales inaugura um período de domínio oligárquico, representando as oligarquias centrais (paulista e mineira) em aliança com os grupos oligárquicos periféricos, consagrando os fenômenos conhecidos como "política dos governadores" e "aliança café-com-leite".

Apesar da rearticulação da economia latino-americana neste período se realizar sob bases independentes das metrópoles ibéricas, é uma unanimidade entre os historiadores de que ocorreu a manutenção

5 WASSERMAN, Claudia. História contemporânea da América Latina. 1900-1930. Porto Alegre: EDUFRGS, 1992, p. 10. 
da estrutura social herdada das colônias. Os novos países permaneceram predominantemente agrários, com base no latifúndio, mantiveram as relaçōes de produção pré-capitalistas e uma nova dependência dos centros de comercializaçăo e financiamento externos.

A grande discussão da historiografia latino-americana se refere à caracterização da estrutura de classes da América Latina e, especialmente, à definição de seus grupos dominantes. Para Otávio Ianni ${ }^{6}$ as oligarquias apresentavam características econômicas, políticas e sociais típicas de uma "dominação patrimonial", nāo possuindo portanto uma organização em termos de relaçốes de classes. Indica que as relações de produção, a cultura e as relações sociais estavam impregnadas de elementos semelhantes àqueles que caracterizavam a sociedade de castas. $^{7}$

Enrique Gomariz Moraga ${ }^{8}$ faz uma diferenciação entre o grupo que ele chama de "oligarquia exportadora" e os "terratenentes tradicionais". Os primeiros constituem, para o autor, "um número relativamente reduzido de capitalistas que conseguiram ligar a propriedade das fontes de matérias-primas à comercialização exterior", enquanto os terratenentes tradicionais seriam aqueles cujo "produto da terra tem uma relação débil (ou nem sequer a tem) com a exportação". Neste sentido, Moraga relaciona o caráter capitalista ou não das classes dominantes segundo suas ligações com o mercado externo, o que obviamente não podemos aceitar para a caracterização de uma classe social. As relações sociais de produção, as representaçóes mentais, as práticas políticas, bem como o substrato cultural devem estar presentes nesta definição histórico-sociológica.

No livro Introducción a una teoria de la história para América Latina, Luis Vitale ${ }^{9}$ insiste na tese da consolidação de relaçóes capitalistas de produção na segunda metade do século XIX em todos os países latino-americanos, chegando mesmo a denominar os grupos dominantes pós-independências de "burguesia criolla". Esta, segundo

6 IANNI, Octávio. La formación del Estado populista en América Latina. México: Era, 1975, p. 70.

? Idem, ibidem, p. 72.

8 GOMARIZ MORAGA, Enrique. O Estado nas sociedades dependentes. O caso da América Latina. Lisboa: Presença, 1977, p. 48-49.

9 VITALE, Luis. Introducción a una teoria de la história para América Latina. Buenos Aires: Planeta, 1992, p. 111. 
o mesmo autor, vinha se gestando desde o período colonial com um processo de acumulação capitalista que se ampliou com a ruptura do nexo colonial.

Agustín Cueva é certamente contrário à tese da acumulação capitalista na colônia, na medida em que, parafraseando o historiador mexicano Enrique Semo, utiliza nas primeiras páginas de seu ensaio a expressão "desacumulação originária" para retratar a sucção de excedentes que se fazia na direção das metrópoles absolutistas no período colonial ${ }^{10}$. Em relação às elites primário-exportadoras do período seguinte, Cueva as compara aos que Lênin chamou "junkers" e cita autores como Rodney Arismendi e Julio Godio que falam de "prussianismo agrário capitalista". ${ }^{11}$ Considera que estas oligarquias tinham características pré-capitalistas, mas que foram responsáveis pelas tarefas de implantação do modo de produção capitalista na América Latina, tendo sido capazes, ao mesmo tempo, de resistir à modernização capitalista e assimilar seu curso inevitável pela expansão mundial do sistema.

As teses de Agustín Cueva aproximam-se muito do entendimento adequado em relação a esse período da história dos países latinoamericanos, pois apontam a contradição que vivem as classes dominantes da época. As próprias discussões historiográficas precedentes levam à conclusão de que as oligarquias eram grupos contraditórios em termos de representaçóes e práticas sociais.

Em um trabalho especialmente dedicado ao desenvolvimento do projeto oligárquico, Marcello Carmagnani coloca que,

"Las oligarquias intentarán escapar a esta contradicción funda-
mental con una huída hacia adelante: en lugar de renovar estruc-
turas, tratarán de potenciarlas y darles una nueva oricntación. Este
esfuerzo por conciliar los nuevos elementos con los viejos apare-
cerá tiempo después como fuente de contradicciones tales e tan
grandes que provocará el fracasso del proyeto oligárquico en un
plazo relativamente breve."12

As economias latino-americanas do período que se inicia por volta de 1850/80 eram caracterizadas pela presença marcante do lati-

\footnotetext{
10 Cueva, op. cit., 1977 , p. 13.

11 Idem, ibidem, p. 79-80.

12 CARMAGNANI, Marcello. Estado y sociedad en América Latina 1850-1930. Barcelona: Crítica, 1984, p. 10.
} 
fúndio, cujos produtos destinavam-se ao mercado externo, o que ensejou a popularização da expressão "desenvolvimento para fora". Mesmo assim, essas sociedades transitaram, ainda que de uma forma particular, no sentido da realização de sua acumulação originária. E esse processo foi realizado sob os auspícios de uma elite nãocapitalista: as oligarquias.

O processo de acumulação originária de capitais somente se reali$\mathrm{za}$ através de um movimento histórico do qual fazem parte dois fenômenos intimamente interligados: a constituição da propriedade capitalista dos meios de produção e a criação de uma mão-de-obra "livre", ou liberada de toda propriedade. Como as características de cada região produtora eram distintas para as várias porçôes do território latinoamericano, em termos de propriedade da terra e tipo de mão-de-obra, a tipologia de Ciro Cardoso e Pérez Brignoli aproxima-se muito do que de fato ocorreu nos diferentes países. Segundo eles a transição à constituição da propriedade capitalista da terra e ao assalariamento ocorreu através de três processos básicos: as reformas liberais em países de densa população indígena, onde a terra estava imobilizada nas mãos da Igreja e das comunidades nativas; a abolição da escravidão em países que utilizaram largamente a mão-de-obra escrava africana; e a colonização de áreas vazias nas regiões que no período colonial não foram muito importantes para a acumulação metropolitana. ${ }^{13}$ Assim mesmo, as oligarquias lutaram contra a transformação completa do modo de produção e, embora tenham se empenhado na apropriação da propriedade que estava em mãos alheias ou livre, mantiveram e até mesmo redobraram, em alguns casos, as relaçóes précapitalistas de produção. Essa manutenção ou aumento das relações pré-capitalistas de produção estiveram muito relacionados com a grande expansão da demanda internacional a partir de aproximadamente 1880 e a simultânea escassez de mấo-de-obra, determinada pela abolição da escravidão ou pela mudança de eixo da economia de exportação, ou seja, troca de regiāo ou produto de exportação. Para isso, as oligarquias tinham extrema agilidade: caso imensas regiões anteriormente produtivas decaíssem, ou algum produto sofresse concorrência incontrolável no mercado internacional, as classes dominantes rapidamente modificavam as regiões e os produtos para atender a

13 Flamarion CARdoso, C., PÉREZ BRIGNOLI, H. História econônica da América Latina. Rio de Janeiro: Graal, 1983, capítulo III. 
demanda dos países centrais. No caso específico da plantação de guano no Peru, a oligarquia recorreu à importação de mão-de-obra chinesa no sistema "indentured servants", devido à falta de trabalhadores na região. Nas fazendas mexicanas existia uma estrutura extremamente hierarquizada e a distinção entre empregados de confiança e peões. Os primeiros estavam vinculados ao patrão por um contrato de trabalho oral e ligados a ele por relações de compadrio, enquanto os peões chegavam a ser considerados "hijos de la hacienda", caso se tratassem de trabalhadores permanentes, o que indica o grau de paternalismo e dependência pessoal presentes nessa relação. No Chile estava presente o fenômeno da "inquilinagem". O inquilino também morava na fazenda e tinha um contrato de trabalho oral, um tipo de relação intermediário entre o colono e o peão. No Brasil, a abolição da escravidão não terminou com o trabalho escravo na maior parte do país, mas para contornar a falta de braços, mesmo antes de abolida a escravidão, as oligarquias recorreram à imigração européia. As relações de trabalho dos "parceiros" nas fazendas de café do sudeste brasileiro eram tipicamente pré-capitalistas. Para abastecer os centros mineiros bolivianos, chilenos e peruanos, o sistema empregado foi o "enganche", que consistia em atrair camponeses e pequenos proprietários com dívidas, que se ligam indefinidamente aos proprietários das minas.

Em todos os casos, é evidente a permanência ou reativação do passado colonial na estrutura social da segunda metade do século XIX. Em relação à força de trabalho, o latifúndio controlava sua população interna, menos mediante assalariamento e mais através de mecanismos servis, onde se conjugavam elementos repressivos e paternalistas. Além desses métodos de importação de trabalhadores e manutenção desses no latifúndio, as oligarquias exigiam um redobramento da jornada de trabalho em troca da mesma retribuição na forma de salários, espécies ou abatimento das dívidas, para aumentar as rendas obtidas com o comércio exportador. Nestes casos, a acumulação de capitais se realiza através do redobramento da exploração e a "evolução" ou "progresso" ocorrem através da extração de mais-valia absoluta, o que patentiza o caráter reacionário da apropriação de excedentes.

Outro dado que atesta o caráter reacionário do desenvolvimento latino-americano é que ele se realiza sem a introdução de conhecimentos, técnicas e instrumentos verdadeiramente modernos. A produção primária é, na maior parte dos casos, extensiva e a técnica predo- 
minante nas minas de extração de prata é a ultrapassada precipitação através do amalgama de mercúrio. Desta forma, o desenvolvimento das forças produtivas ocorre, mas de uma forma muito lenta, embora nas áreas onde o trabalho livre se impõe, esse desenvolvimento tenha sido mais acelerado. Segundo Agustín Cueva,

"resulta claro, por lo demás, que en América Latina el ritmo de este desarrollo varía en razón inversa del grado de 'hibridez' de las relaciones sociales de producción." 14

A primeira observação que se coloca, portanto, em relação às práticas oligárquicas é de que estes grupos foram capazes de um esforço produtivo e acumulação de capitais proveniente das exportaçóes de produtos primários, sem entretanto modificar as relações sociais de produção no latifúndio, que serviam de base para toda a renda, prestígio e poder que as oligarquias acumularam.

O predomínio de relações pré-capitalistas de produção impediu, além do mais, que todo o esforço produtivo extensivo se traduzisse na aparição de uma nova sociedade. A crescente prosperidade dos latifundiários latino-americanos se traduzia na construção de moradias suntuosas nas cidades e transformação de suas casas de campo em verdadeiros palácios.

Outro dado que atesta uma certa prosperidade diz respeito à construçăo de ferrovias e portos, cujos investimentos principais eram realizados com capitais estrangeiros, especialmente inglês. $\mathrm{O}$ desenvolvimento de uma rede bancária, de serviços mercantis, de uma burocracia estatal e serviços urbanos também estão ligados ao comércio externo. As cidades, entretanto, mantém os problemas tradicionais: elevado índice de mortalidade, freqüentes epidemias e baixíssimo nível de vida das classes populares. A ampliação dos serviços urbanos e da burocracia estatal, bem como a participação das oligarquias em atividades não agrárias, como a bancária e comercial, tinham como objetivo único otimizar a produção primária, e se foram responsáveis por uma diversificação econômica e social, esse não era o objetivo preciso das oligarquias. O núcleo dos interesses oligárquicos permanece centrado na terra, e também a terra era um polo de atração para setores enriquecidos por outras vias,

14 Cueva, op. cit., 1977 , p. 83. 
"[...] los mineros enriquecidos - chilenos, bolivianos o mexicanos - se convierten en hacendados ya en la primera generación. Esta propensión no es exclusiva de los mineros; la hallmos tambiém en los políticos, y la política es, como demuestran las gucras civiles, una de las vías posibles para convertirse en hacendado. A la fascinación ejercida por el latifundio no escaparon siquiera los comerciantes extranjeros. Éstos, cuando se enriquecen, son admitidos por cooptación en la clase dominante y se transforman rápidamente en hacendados." 15

A grande propriedade que proporciona mais prestígio do que rendas se constitui no elemento básico através da qual se organiza o poder. As outras atividades - burocracia, manufaturas, comércio, bancos, etc. - são consideradas como complemento daquela atividade que possibilita o total domínio sobre os homens: a propriedade da terra.

Os efeitos econômicos e sociais desse desenvolvimento está diretamente relacionado com o predomínio do latifúndio e o desprezo por outras atividades produtivas: do ponto de vista social, ocorre uma demora na formação de um proletariado e uma burguesia modernos. A burguesia industrial propriamente dita, nasce "confundida e entrelaçada" com os grandes proprietários, ${ }^{16}$ muitas vezes são os próprios oligarcas que investem no setor industrial por causa das crises cíclicas do setor primário-exportador. Assim, a maior parte das indústrias criadas neste período seguem um padrão tradicional, caracterizado por pequenas unidades de baixa eficiência ou que desenvolvem atividades complementares à produção primário-exportadora.

Do ponto de vista econômico, a oligarquia impôe sérios limites ao desenvolvimento de um mercado interno, devido à pauperização das classes populares e a manutenção do trabalhador rural preso à terra. Opera-se uma atrofia das atividades destinadas ao consumo interno que era correlata da hipertrofia do setor destinado à exportação de produtos primários.

$\mathrm{Na}$ verdade o mercado interno latino-americano se consagra como um prolongamento do mercado externo. O intercâmbio desigual de mercadorias primárias por produtos manufaturados é responsável por mais essa deformação na estrutura nacional dos países da América Latina. A íntima aliança das oligarquias latino-americanas com o ca-

\footnotetext{
15

16

Carmagnani, op. cit., 1984, p. 57.

Cueva, op. cit., 1977 , p. 85.
} 
pital externo, na forma de empréstimos aos governos, construção de obras de infra-estrutura e participação nos lucros alfandegários provoca ainda um processo de desnacionalização econômica e deformação ainda maior no aparato produtivo nacional, pois as inversões ocorrem preferencialmente nos setores interessantes ao capital monopólico, auxiliando no processo de sucção de excedentes.

As oligarquias primário-exportadoras exerciam seu predomínio não só no campo socioeconômico, mas também deixavam sua marca tradicional nos setores político, cultural e ideológico.

Até 1880 , dois terços de toda a população latino-americana era analfabeta. $\mathrm{O}$ ínfimo número de pessoas inscritas nas universidades indica que o acesso à cultura estava reservado aos membros das oligarquias. Nas zonas de maior densidade populacional, zonas de controle cultural para as classes dominantes, a porcentagem de alfabetizados aumentava um pouco e uma porção significativa dos que desembocavam em idade adulta nos mecanismos produtivos e na atividade social, passavam pela escola primária. Os conteúdos da escola primária e mesmo das universidades contribuíam para criar uma mentalidade estreitamente oligárquica. Uma mentalidade que ultrapassa o período oligárquico e que era proclamada por religiosos e até mesmo por liberais como Bolivar, por exemplo. Se consideravam herdeiros dos conquistadores e propunham a manutenção dos privilégios que eram tributários da sociedade colonial, como um pagamento pelos seus serviços e para "proteger" os índios.

François Chevalier coloca que,

"[...] adotaban respecto a los indios un sentimento ambiguo de solidariedad telúrica y de superioridad."

A partir dessas concepçóes a respeito do "outro" é que as elites latino-americanas começam a se auto-identificar; construíram-se a partir da exclusão. O que se excluía era um inimigo real, virtual ou imaginário. Podia constituir-se num aspecto territorial, cujos exemplos mais importantes são a Guerra do Pacífico (1879-1884), na qual o Chile vence o Peru e a Bolívia, e a Guerra da Tríplice Aliança (1865-1870), na qual pelo menos Argentina e Brasil puderam demonstrar a força de suas elites. A exclusão também pode basear-se no

17 CHEVAlier, François. América Latina de la independencia a muestros dias. Barcelona: Labor, 1979, p. 275. 
orgulho de pertencer à raça branca e à cultura ocidental. Nos países de densa população indígena, africana ou mestiça a cruzada racista oligárquica estava destinada a "branquear" toda a população, ou em todo o caso, torná-la mais mestiça.

Além do processo de controle social e político se realizar através da exclusão dos supostos inimigos nacionais, também havia o controle da inclusão de pessoas aos círculos oligárquicos. O imigrante europeu, por exemplo, era admitido como promotor de um esquema de organização social onde ele, por ser europeu e de pele branca, tinha lugar assegurado. Foi admitido como "gestor da grandeza nacional" na Argentina, por exemplo, até o momento em que esses mesmos imigrantes foram identificados como aqueles que formavam sindicatos anarquistas, organizavam greves e lutavam contra as forças repressivas.

Outro setor social favorecido pelo esquema oligárquico era o dos trabalhadores na administração pública e serviços urbanos. Apesar de constituírem o embrião das classes médias, que num futuro próximo questionariam o poder oligárquico, esta burocracia estatal possuía um status econômico e social bem superior ao das classes populares, o que de certa maneira garantia fidelidade incondicional desse grupo de burocratas aos interesses das classes dominantes. Um mecanismo clientelístico, semelhante ao utilizado nas grandes propriedades com os "mordomos" - capatazes - que residiam na fazenda. Através do sistema eleitoral censitário imperante em quase todos os países, os burocratas podiam votar, ser votados, o que simultaneamente lhes assegurav ${ }^{\prime}$ a condiçăo de cidadãos, parte do sistema oligárquico, e também possibilidades de crescimento político-social a ponto de questionar esse sistema. Para M. Carmagnani,

"La oligarquia le ofrece un modelo cultural que imitar, impidiéndole así que desarrolle una identidad própia, dado que la máxima aspiración de los miembros de este grupo consiste en llegar a formar parte de la clase oligarquica." $" 18$

Este parece constituir-se em mais um elemento que explica a permanência das forças oligárquicas no poder político dos países latino-americanos, mesmo quando já não são classes dominantes do ponto de vista econômico e hegemônicas politicamente.

18 Caramagnani, op. cit., 1984, p. 64. 
Apesar das grandes revoltas camponesas, operárias e de grupos urbanos, o período apresentado neste ensaio, entre 1880 e 1920 , apresenta-se como um momento de extrema estabilidade oligárquica, porque as oligarquias haviam sido capazes de coibir o desenvolvimento das contradições geradas por esse tipo de implantação do capitalismo. Os princípios do liberalismo, em geral aceitos pelas elites latinoamericanas, estavam unicamente restritos ao livre comércio, enquanto os alicerces do poder político estavam fundados sob formas de mediação extremamente autoritárias. Mesmo na passagem do sistema censitário de sufrágio para um sistema universal, admitia-se apenas a população masculina, adulta e alfabetizada, o que não passava de vinte por cento de toda a população dos países. Na prática, essa transformação eleitoral, reivindicada por grupos que começavam lentamente a criticar o sistema oligárquico, independente de seu conteúdo inovador, somente aumentou o poder político das áreas rurais. Os latifundiários passaram a manipular listas eleitorais segundo suas conveniências, reduzindo assim, por muito tempo, o peso dos grupos urbanos. Por isso, todos os movimentos anti-oligárquicos que partiam das cidades exigiam a moralização do sufrágio e a reforma completa do sistema eleitoral.

Assim, enquanto a maior parte dos estudos sobre o período oligárquico, incluindo um trabalho anterior desta mesma autora, ${ }^{19}$ insistem em apresentar os avanços em direção ao desenvolvimento do capitalismo, indicando com cifras a prosperidade do setor primárioexportador, o início da industrialização, o crescimento de infra estrutura, o desenvolvimento urbano, etc., este ensaio tratou de mostrar a manutenção, a conservação e a persistência das classes dominantes. Estas elites, embora tenham sido responsáveis pela implantação do modo de produçăo capitalista, o fizeram a sua maneira, retardando o aparecimento de relações sociais que pudessem extinguir com seu poder.

As oligarquias latino-americanas resistiram tanto tempo quanto lhes foi possível à implantação do trabalho assalariado em regiōes onde ainda era possível utilizar mão-de-obra servil. Esta thes garantia domínio sobre grupos imensos da população, riqueza e manutenção do poder político. Também foram responsáveis pela obstaculização de outras atividades produtivas, como a industrialização por exemplo;

19 Wasserman, op. cit., 1992. 
não porque a indústria em si constituísse uma ameaça à sua continuidade no poder, mas porque era praticamente incompatível a política econômica voltada para o setor primário-exportador e uma política econômica que defendesse os interesses do setor industrial, no que se refere à taxas cambiais, protecionismo alfandegário, decisão de investimentos, crédito, etc.

Entretanto, quando refrear a expansão da burguesia tornou-se impraticável, as oligarquias já estavam solidamente instaladas como uma fração da classe dominante nacional. Somente no México, onde ocorreu uma Revolução burguesa à exemplo das revoluçōes européias, e nos países que se dirigiram ao socialismo - Cuba e Nicarágua - as oligarquias foram violentamente arrancadas do poder. Nos outros países, elas permaneceram como grupo subordinado das classes dominantes nacionais, mas cujas propriedades são até hoje intocáveis. Como coloca Florestan Fernandes, ${ }^{20}$ para o caso brasileiro, mesmo nos países que não conheceram uma Revolução burguesa como a francesa, ocorreu um processo nos quais as tarefas de implantação do capitalismo foram realizadas. Nestes países, tais como no Brasil, ocorreu um processo que não apresentou rupturas cronológicas, mas foi violento, rápido no tempo e marcado pela acomodação, ou seja, um processo transado entre as elites para manter as classes populares afastadas da possibilidade de grandes transformaçöes. As oligarquias foram responsáveis pela realização dessas tarefas burguesas e mantiveram-se ao lado do desenvolvimento capitalista, ainda que um desenvolvimento particular. Como salienta Agustín Cueva em Teoria social y procesos politicos en América Latina,

“[...] nuestra situación de 'subdesarrollo' puede caracterizarse, en un primer acercamiento, como la situación de un conjunto de sociedades que padecen no sólo los males que entraña el desarrollo del capitalismo, sino también y, simultáneamente, los que se derivan de su falta de desarrollo (paráfrasis de un conocido texto de Marx) [...] caracterizados por una acumulación muy particular de contradicciones que van desde las derivadas de la existencia de secuelas o elementos precapitalistas, hasta las inherentes a la presencia del capitalismo en su fase más avanzada, imperialista." ${ }^{21}$

2) FERNANDES, Florestan. A Revolução Burguesa no Brasil. Rio de Janeiro: Zahar, 1976.

${ }^{21}$ CUEVA, Agustín. Teoria social y procesos políticos en América Latina. México: Edicol, 1979, p. 9. 
O grau e o ritmo de desenvolvimento do capitalismo na América Latina e da permanência das velhas oligarquias varia de um país para outro em virtude de determinações históricas peculiares a cada formação nacional. Assim como existe desigualdades entre a América Latina e outros continentes, também existem diferenças no interior da área latino-americana, fato que dá origem à super estruturas e processos políticos diferenciados entre si. Entretanto, tudo isso ocorre no marco de uma unidade definida por coordenadas histórico-estruturais comuns, o que permite estudá-las como conjunto, preservando os traços particulares.

Neste sentido, pode-se afirmar que, na imensa maioria dos países da América Latina, as "forças da permanência" estão presentes quando ao estudar essas sociedades concluí-se que os aspectos mais visíveis da realidade desses países são as desigualdades sociais, a pobreza, a persistência da exclusão, a violência política e social, etc.

A permanência da exclusão social comprova-se, por exemplo, quando os informes econômicos dão conta de que no Brasil aproximadamente um terço de toda a populaçáo não participa da economia capitalista, não forma parte do mercado de trabalho e tampouco do mercado consumidor. Estas cifras estăo presentes em muitos países da América Latina em maior ou menor grau, o que atesta a permanência de características do sistema social oligárquico, que simplesmente excluía parte da população dos benefícios sociais. Pese as agruras que passa a população que é excluída, esta exclusăo năo é característica inerente ao modo de produção capitalista e é um dos maiores fardos que a burguesia latino-americana carrega.

Uma questão que năo está necessariamente relacionada com a exclusão é a da concentração da renda, da riqueza e do poder. Este problema não relaciona-se com a exclusão porque toda a sociedade capitalista é tipicamente concentradora, mas na América Latina esta característica é exacerbada ao extremo de não permitir uma adequada ampliação do mercado de consumo, popularizando a idéia de que existe uma espécie de apartheid social nos países latino-americanos.

A segregação ao qual está submetido grande parte do povo latinoamericano também está relacionada com a manutenção da tradição oligárquica, principalmente no que se refere ao preconceito racial. Ainda que de forma velada, na maioria dos países latino-americanos, as elites dominantes mantém a concepçáo da superioridade da raça branca frente ao mundo indígena ou africano. E a apologia da mesti- 
çagem, efetuada inclusive por pensadores progressistas como o mexicano José Vasconcelos, tende a redobrar a discriminação contra as minorias nacionais.

A existência de grandes desigualdades regionais também é fruto de uma permanência da tradição oligárquica. As regiōes que acumularam capitais através do setor primário-exportador e que foram privilegiadas no contexto político do sistema oligárquico, foram as regiōes que mais cresceram e se industrializaram e que seguem liderando grande parte das riquezas do país, dando origem a fortes atritos. No Brasil, esta região é o Sudeste cafeeiro; na Argentina, o porto de Buenos Aires; no Chile, a região mineradora, assim como no Peru e no México. Nos países do capitalismo central, a própria forma como se implanta o modo de produção promove uma tendência à homogeneização regional, ou pelo menos, a aceitação da divisão interna de trabalho.

Outro problema recidivo é o da dependência estrutural. Apesar das grandes discussões acerca da teoria da dependência, este fenômeno obviamente não desapareceu e constitui-se como uma das mais fortes características de nossas sociedades. As oligarquias não foram responsáveis pela dependência, mas foram certamente os primeiros grupos dominantes latino-americanos a estabelecer uma vinculação com o capital monopólico, difícil de romper mesmo nos momentos mais nacionalistas, como foram os governos populistas de Vargas e Perón, ou as revoluçôes boliviana e guatemalteca da década de 50 .

Em relação às práticas políticas das elites latino-americanas percebe-se também uma tradição que remonta o período dominado pelas oligarquias primário-exportadoras. As burguesias nacionais da maior parte dos países da América Latina só conseguem dominar através de formas políticas extremamente autoritárias; o consenso raramente é predominante no frágil equilíbrio de poder dessas elites. Isso se explica por, pelo menos, duas razões. Em primeiro lugar, a "força da tradição" acostuma, de certa maneira, as elites a governarem sem a presença ou a ingerência do "povo". Em segundo lugar, e mais importante, é que a permanência das oligarquias no interior das classes dominantes, como uma fraçăo secundária, porém influente, obriga a totalidade da classe social a manter a exclusão dos grupos que questionam a problemática agrária, diretamente vinculada à tradição oligárquica, e que nem de longe foi solucionada em quase toda América Latina, exceçăo feita ạos países socialistas. 
E, finalmente, foi mantida a "velha" estrutura agrária, determinada pela força do latifúndio em países como o Brasil, o Peru, o Uruguai, a Argentina e quase todos da América Central, com exceção daqueles que, à força de uma revolução, realizaram uma reforma agrária. Mesmo nos países onde foi realizada uma reforma agrária capitalista, como no México, por exemplo, os problemas agrários nấo foram suficientemente solucionados como pode-se observar com a renovaçāo do movimento zapatista em Chiapas.

Portanto, as oligarquias primário-exportadoras latino-americanas são comparadas neste ensaio às nobrezas européias do antigo regime; os Estados absolutistas aos Estados oligárquicos. Guardando as devidas precauçōes teórico-metodológicas, pode-se afirmar que os dois períodos se caracterizam pelo confronto entre o novo e o velho, o progresso e a tradição; as chamadas "forças de permanência" foram capazes de uma reorganização, apesar da transição em andamento. Se, segundo Arno Meyer, ${ }^{22}$ apesar da grande ruptura revolucionária francesa, as elites aristocráticas mantiveram-se poderosas até pelo menos 1914, é também lícito afirmar que no processo latino-americano de "acomodação" as elites oligárquicas mantiveram-se como parte integrante do processo de transição ao capitalismo e não como antagônicas.

Os movimentos que deram início à chamada crise das oligarquias, como a Revolução Mexicana, a Reforma Universitária de Córdoba, o Movimento Tenentista e a revolta dos inquilinos no Panamá, foram indícios de uma crise que ampliou-se a cada passo. Mas essa não era exatamente a crise de uma fração da classe dominante latinoamericana que ao final do ciclo desapareceria, dando lugar à grupos mais ou menos progressistas. Era o início de uma permanente crise hegemônica do conjunto das classes dominantes da América Latina. Por causa da permanência de frações reacionárias, incorporação de um espírito conservador e acomodação de grupos diferentes, mas não antagônicos, as classes dominantes latino-americanas não são hegemônicas, ou seja, não podem atender minimamente os reclames de uma população agrária expropriada e faminta, sem ferir os interesses de uma de suas partes. Apesar da Revolução Mexicana e da reforma agrária que se seguiu ao processo revolucionário, assiste-se com inex-

22 Meyer, op. cit., 1990. 
plicável espanto às ameaças de "revolução dentro da revoluçăo" pelos camponeses de Chiapas, que reivindicam o mito de Emiliano Zapata, como prova da permanência de relações sociais extremamente híbridas no campo; a vitória de Hipólito Yrigoyen na Argentina e a espetacular Reforma da Universidade que percorreu um a um dos países da América Latina, cedeu lugar a uma violenta retomada das oligarquias já na década de 1930 , com a reedição do domínio oligárquico na chamada Década Infame (1930-1943); no Panamá, a indústria do transporte sobreviveu às reivindicações populares e as oligarquias panamenhas às revoltas de inquilinos, pelo menos até o fim do tratado de concessāo do canal aos Estados Unidos que se encerra em 1999; e, finalmente, o Movimento Tenentista e toda a crise dos anos 20 no Brasil não impediram a continuidade das oligarquias no predomínio das relações sociais e de poder no país, exemplificadas pela vitória eleitoral de Fernando Collor em 1989, pela manutenção do poder político-eleitoral de determinados caciques do nordeste brasileiro, como é o caso de Antônio Carlos Magalhães, bem como pela enorme bancada legislativa da União Democrática Ruralista e da continuidade da violência social no campo.

Um dos principais problemas que os países latino-americanos recém-redemocratizados enfrentam hoje, nos remete ao passado, ao momento da crise das oligarquias - a democracia foi reduzida ao seu momento estritamente eleitoral; desde que classes médias urbanas, proletariado, campesinato e outras fraçōes afastadas do aparato de poder oligárquico reivindicaram o fim do domínio exclusivo dos grupos primário-exportadores, pouco se avançou no sentido de eliminar os obstáculos que essas oligarquias impõe ao desenvolvimento capitalista dos países do subcontinente, exemplificado nas questóes descritas anteriormente.

Muito embora os principais grupos oligárquicos sobreviventes na política latino-americana nāo tenham podido conter o predomínio do sistema capitalista no subcontinente, eles puderam adaptar o seu comportamento pré-capitalista, sem no entanto abdicar dos privilégios sociais, dos interesses agrários e de sua concepção de mundo.

Note-se que esta é apenas uma perspectiva de trabalho, ao invés de estudar o progresso e os motivos da decadência das oligarquias, contemplar as permanências e suas causas. Entretanto, esse pequeno ensaio não comporta uma ampla investigação empírica e tão pouco 
um rigor teórico-metodológico necessários à comprovaçāo desta nova perspectiva de trabalho. Além disso, o ensaio permite generalizações que uma investigação mais aprofundada talvez não comportasse. Uma pesquisa rigorosa sobre o tema e um marco conceitual adequado permitiriam inclusive entender os obstáculos ao desenvolvimento capitalista que estas resistências provocaram em alguns países da América Latina, tarefa que não foi imposta ao presente estudo. 